\title{
Religious Studies Postgraduate Essay Prize
}

Submissions are invited for the Religious Studies Postgraduate Essay Prize, which is sponsored jointly by Cambridge University Press and the British Society for the Philosophy of Religion. The winning entry will be published in Religious Studies, and the winner awarded £300.

The Prize is an international prize, and open to all those who, at the time of the deadline, are registered for a postgraduate degree. The topic of the essay should be in the philosophy of religion and must be no longer than 10,000 words in length. The judges reserve the right not to award the Prize if no submission of sufficient merit is received. All entries will be considered for publication in Religious Studies.

Essays should be submitted in hard copy only (not through the journal's electronic submission system), in duplicate, and clearly marked 'Religious Studies Essay Prize', with the author's name and contact details in a covering letter but not on the essay. The closing date for entries is 31 December 2014, and they should be sent to:

Prof. Robin Le Poidevin

Editor, Religious Studies

School of Philosophy, Religion and History of Science

University of Leeds

Leeds LS2 9JT

UK 